$$
\text { 氏 } \quad \begin{aligned}
& \text { 名 がが のり } \\
& \text { 上 垣 憲 雅 }
\end{aligned}
$$

学位 の種 類 博士 (医学)

学位記番号甲第 526 号

学位授与年月日 平成 17 年 9 月 30 日

学位授与の要件 学位規則第 4 条第 1 項該当

学位論文題目 PTEN-positive and phosphorylated-Akt-negative expression is a predictor of survival for patients with advanced endometrial carcinoma

（進行子宮内膜癌において PTEN 発現陽性かつリン酸 化 Akt 発現陰性は予後良好の指標となる)

学位論文審査委員 （主査） 清 水 英 治 （副查）井藤久雄寺川直樹

\title{
学位論文の内容の要旨
}

PTEN 遺伝子は第 10 番染色体に位置し、ヒトの悪性董瘍において最も高頻度に变異を認める癌 抑制遺伝子のひとつである。PTEN は脂質脱リン酸化醥素であり、ホスファチジルイノシトール 3 リン酸の 3 位に作用する。PTEN はホスファチジルイノシトール 3 キナーゼ（PI3K）の作用に拮 抗し、セリンススレオニンキナーゼである Akt を負に制御している。P13K の作用によりリン酸化 され活性化された Akt は、細胞増殖や生存に関連した下流のさまざまな蛋白の活性化に関与して いる。

膠芽董、䧛腅癌および黑色董といった悪性偅瘍の予後と PTEN 発現との関連が多数報告されて いる。これらはすべて、PTEN の不活化が予後不良に関係するというものである。しかしながら、 子宮内膜癌においては、PTEN の変異は予後良好の指標となるとの報告が見うけられる。教室では、 進行内膜癌において PTEN 発現陽性はむしろ予後良好の指標であると報告してきた。したがって 本研究では、PTEN/Akt 系路が子宮内膜癌の予後に与える影響を明らかにしようとした。

\section{方 法}

1985 年から 2000 年の間に初回治療を行った手術進行期吕 $c$ およびIV期の子宮体部類内膜腺癌 99 症例を対象とした。患者の同意を得て、摘出子宮のパラフィン包埋切片を用い PTEN、リン酸 化 Aktおよび細胞増殖の指標となる Ki-67 の免疫組織染色を行った。PTEN染色については、すべ ての董湯細胞が染色される場合に PTEN 発現陽性とし、染色陽性細胞と陰性細胞の混在するもの をPTEN 発現混在と定義した。Ki-67 に関しては 1000 個の細胞を計測し、その陽性細胞比率を labeling index ('LI ) として算出した。各種蛋白発現と累積生存率との関連を検討した。 
結 果

99 症例のうち PTEN陽性は 34 症例に、PTEN 陰性・混在は 65 例にみられた。リン酸化 Akt 陽性 は40 例にみられた。PTEN 発現とリン酸化 Akt 発現との関連については、リン酸化 Akt の陽性率 は PTEN陽性例で 24\%にみられたのに対し、陰性・混在例では 49\%にみられ、有意に高值となっ た。リン酸化 Akt 陰性例は有意に良好な生存率を示した。

次に、PTEN 発現とリン酸化 Akt 発現とを組み合わせて検討した結果、PTEN 陽性かつリン酸化 Akt 陰性例の生存率は有意に高く、多変量解析において FIGO 進行期とともに独立予後因子となっ た。リン酸化 Akt 発現と Ki-67 LI との関連では、リン酸化 Akt 陰性症例の K i-67 LI の中央值は リン酸化 Ak t 陽性症例に比して有意に低かった。リン酸化 Akt 発現を指標として ROC 曲線より算 出した Ki-67 LI のカットオフ值は 25\%となり、25\%以上の II を示す症例の予後は有意に不良と なった。

\section{考察と結論}

子宮内膜癌の臨床検体において、PTEN 発現とリン酸化 Akt 発現との間には負の相関が存在する ことを Pestern blot 法で見い出し、以前に報告したが、免疫組織染色を用いた今回の検討でこ の相関を確認することができた。一方、子宮内膜癌症例において PTEN の变異は早期癌またはリ ンパ節転移のない症例に多く、進行癌症例ではPTEN の変異が少なかったことから、PTEN の変異 は予後良好の指標となるとRisinger らは報告している。

PTEN 機能の岥失に伴う Akt の活性化は、子宮内膜癌の增殖・進展に重要な役割を持つと推測さ れる。本研究ではリン酸化 Akt 発現と予後との関連を検討し、リン酸化 Akt 陰性例は予後良好で あることを明らかにした。次に、PTEN 発現とリン酸化 Akt 発現とを組み合わせることにより、PTEN 陽性かつリン酸化 Akt 陰性が進行内膜癌の独立予後因子となり、予後良好の指標となることを示 した。Ki-67 の免疫組織染色においてリン酸化 Akt は Ki-67 LI と関連し、LI の低值が予後良好 となった。

本研究成績より、進行内膜癌症例において PTEN 陽性かつリン酸化 Akt 陰性は予後良好の指標 となることを明らかにし、PTEN およびリン酸化 Akt 発現の検索は子宮内膜癌治療の個別化への一 助となるものと考察された。

\section{審 査 結 果 の 要 旨}

進行子宮内膜癌99例を対象として、癌抑制遺伝子PTEN / Akt系路が内膜癌の予後に与える影響 を検討した論文である。免疫組織染色の結果、PTEN陽性かつリン酸化Akt陰性例の生存率は有意 に高く、多変量解析において独立予後因子となった。リン酸化Akt発現はKi-67 labeling index （ＬI）と関連し、LIの低い症例の予後は良好であった。

本研究は新知見に富むものであり、その結果は婦人科偅瘍学研究に貢献するとともに学術の水 準を高めたものと認める。 